\title{
Police's Public Relations to Enhance Mutual Understanding in Indonesia
}

\section{Peran Humas Kepolisian Republik Indonesia untuk Meningkatkan Mutual Undestanding}

\author{
Frizki Nurnisya $^{1}$, Suriati Binti Saad ${ }^{2}$, Mahyuddin Ahmad Abdul Rahman ${ }^{3}$ \\ ${ }^{1}$ Universitas Muhammadiyah Yogyakarta, Jl. Brawijaya, Kasihan, Bantul \\ ${ }^{2,3}$ Universiti Sains Malaysia, Level 3, Building C10, USM, Penang \\ *Corresponding author, e-mail: frizkinurnisya@umy.ac.id
}

\begin{abstract}
The study of police public relations is a new phenomenon that has been rising lately. Indeed, along with the growth of modernity, increasing disputes, the need for convergence, and the community environment, there have been increasing demands from the public for the police to make changes in their actions and attitude when dealing with the community. This research uses qualitative methodology as it explores activities carried out by police institutions. Hence, the a case study is a right research method because this research explores the government's agency, especially within public policy. The research result shows that to complete this job correctly, the police need public support, and to maximize this support, the police need the functions of police's public relations at all levels, from the National Police Headquarters to the District Police.

Keywords: Indonesian National Police; Mutual understanding; Police public relations; Public support; Public relations strategy

Abstrak

Kajian tentang humas kepolisian adalah fenomena baru karena saat ini telah ada banyak tuntutan dari masyarakat seiring dengan pertumbuhan modernitas, meningkatnya perselisihan, perlunya konvergensi, dan lingkungan masyarakat yang menuntut polisi untuk melakukan perubahan dalam tindakan dan perilaku ketika berhadapan dengan komunitas. Penelitian ini menggunakan metodologi kualitatif dan karena mengeksplorasi kegiatan yang dilakukan oleh lembaga kepolisian, maka, metode yang tepat untuk penelitian ini adalah studi kasus karena tepat digunakan untuk mengkaji pemerintah daerah, terutama dalam kebijakan publik. Hasilnya menunjukkan bahwa untuk menyelesaikan pekerjaannya dengan tepat dan efisien, polisi membutuhkan dukungan publik dan untuk memaksimalkan dukungan ini, polisi memerlukan fungsi humas kepolisian di semua tingkatan, dari Mabes Polri hingga Kepolisian Resor.
\end{abstract}

Kata Kunci: Dukungan publik; Humas kepolisian; Strategi kehumasan; Mutual understanding; Polisi Republik Indonesia 


\section{Introduction}

Almost all countries worldwide have police departments as they have essential roles in dealing with social conflicts, security management, crime, traffic rules, and disasters (Kocon and Kryszk 2015). The police play a critical role in providing countries with internal security, enforcing the laws establishing national stability, and protecting the community (Offerdahl 2016). As a crucial institution, the police need public support (Muradi 2014). In a democratic country like Indonesia, without public confidence, public trust, and public support, professionalism in police performance cannot be achieved (Marenin and Caparini 2004). It means that police have to maintain mutual understanding with the public to get public support; therefore, the police will have to improve their performance, especially when dealing with society.

However, the existence of police as an individual or as an institution is not entirely accepted by the society as in almost every country the police experience difficulties in improving their image and being favorable in public opinion. The phenomenon happens even in countries that have the most established democratic system (Kadar 2001). For example, in developed countries such as the UK, since the 19th-century, police force became a controversial institution and suffered a permanent crisis for reputation issues related to corruption cases (Mawby 2014). Moreover, Brown and Warner's research in 50 major cities in the United States showed double standards by American police when confronted between residents and immigrant residents in 1990; addressing the practice of racism still carried out by police in the United States, the most democratic country in the world (Brown and Warner 1992). Even today racism still happened again in 2020 when a white policeman in the Minneapolis United States assassinated the black citizen George Floyd. It shows there are still racist acts by the police that will damage the image of police institution (Board 2020), making it even more challenging to have a mutual understanding between the police and the citizen in the US.

The challenge of creating a public relations strategy in maintaining mutual understanding with citizens is a possible aspect of politicization by the President. The President has the legislative right to elect the chief of Police Institution that sometimes benefits his government when they produce rules or strategies. Consequently, it is for the sake of the police's interest that some of the public information is covered. At the same time, Broom and Sha emphasize that it is essential for police public relations to provide plentiful and precise information to strengthen good relations further and establish mutual understanding between police and society (Broom and Sha 2013). The public expects police to provide extensive, open, and transparent information to nurture communication and mutual understanding. Thus, police public relations must continue to establish communication with the people to provide the truth and the correct information to improve their image and generate mutual understanding with the public.

The police public relations officers have to conduct two-way communication without forgetting the institution's integrity (Nielson-green and Army 2011). Therefore, choosing the person in charge of public relations in the police force should come from public affairs science (Nielson-Green 2011). The person must learn, train, and practice every rule that applies in the police institution (Nielson-Green, 2011), as strategic communication that is structured and assisted by human communication can be more effective in building mutual communication.

Information passed through the police public relations has to be honest, transparent, trustworthy, and not just to protect the image of the police organization. 
Public relations must be interpreted as "public information" and not a tool to hide negative things or manipulate information or facts that developed after (Muradi 2016). This is because some of the public affairs in the police institution is a chief who is a combat arms expert but demands the press to "write what you want it to be" (Nielsen 2005).

The study about police institutions in this research explores how police transform their communication and improve public relations functions to enhance mutual understanding. Indonesian National Police, like other police forces in other countries, have specialized divisions that carry out public relations functions and tasks. However, it has not yet become a significant concern for the police regarding the formation and maintenance of a positive image of the police institution in the community because the image work is low in the organizational consciousness (Mawby 2002). Thus, the role of a public relations officer should be noticed by the police as it helps public administrators perform better at 1) implementing the agency's central mission and 2) fulfilling the democratic responsibilities inherent in government (Muradi 2014).

The efforts to develop and manage police images have not been made seriously by police institutions because they are not trained to manage their excellent and positive images favorable in the public's opinion. It implies that what is done by the police institution does not touch the public, but the public adequately record all negative behavior of police personnel (Kadar, 2001). Thus, it makes police institutions, including the Indonesian National Police, struggling to construct mutual understanding with the public.

A case study on the Indonesian National Police needs to be done because the Indonesian police have implemented many strategies to build mutual understanding with their stakeholders. For example, despite meeting the public in person, the INP has produced films such as Pohon Terkenal, Hanya Manusia, and Sang Prawira. The Indonesian National Police also held the Police Movie Festival and even had an official social media account. However, these efforts did not significantly affect the relationship between the INP and the public. The attempts they make do not positively influence the interaction between the INP and the public. Besides, the INP's official accounts also attract poor remarks, scorn, cynicism, insinuation, and intimidation, which continue to happen daily. (Kartika 2009; Masya, Elvina, and Simanjuntak 2012; Nasrullah 2015).

\section{Method}

The research method is essential to satisfy four key characteristics: logical, confirmable, repeatable, and scrutinize-able research (Bhattacherjee 2012). This research employed the qualitative paradigm. It started with planning an issue that has not been discussed before, followed by understanding the purpose and asking some relevant questions. The researcher needs to examine the existing literature, make contact with several individuals, and find ways to enter society and not make predictions (Reeves 1999).

Since this research will explore activities carried out by government agencies, such as police institution, so the precise method to use is a case study because it is useful for exploring local government and/or agency levels, especially within public policy and administration subfield (Yanow, P., and Freitas 2008). Another advantage of using a case study for this research is the possibility of explaining the whole process of creating images of the police to boost mutual understanding. Therefore, this research is a descriptive study that consists of interviewing and analyzing police jobs and activities. 
In addition, comparative analysis in this study is utilized to provide holistic and comprehensive research by combining previous research and literature.

This research uses documentation as primary data. The type of documentation used in this research are letters, memoranda, agenda, study report, or any items that could add to the database. According to Tellis, due to research documentation, the researchers must be extremely selective to avoid incorrect data (Tellis 2014).

The research also uses in-depth interviews to validate and strengthen the evidence that has been found in the documentation. The interview could take one of several forms: open-ended, focused, or structured (Tellis, 2014). This research uses a structured interview and purposive sampling, which is a technique for determining samples for specific purposes by choosing certain people as informants based on particular judgments. Therefore, the informants in this research are Police Brigadier General Syahardiantono as the Head of Information and Documentation Management Bureau Police Public Relations of INP; First Police Inspector Tyan Ludianan Prabowo as the Administrative Officer of Service and Information Section Police Public Relations of INP; and Muhammad Fajar as the government employees Police Public Relations of INP.

\section{Results and Discussion}

\section{Police Public Relations and Police Reform}

The study of police public relations is a new phenomenon. Many demands from the public along with the growing modernity, increasing disputes, the need for convergence, and the community environment require the police to alter their actions and behavior when dealing with the community (Cooke and Sturges 2009). Police public relations in this context are government agencies that preserve the deal with the public in an "open" and "transparent" manner (Mawby 2009). They also act as gatekeepers as they sanction where police images and other information can be relayed to the community (Mawby 2009). Consequently, the police's public relations have a critical role in maintaining the reputation of police organization amidst dynamic community changes.

In 1989, British police, as the first modern police institution, compelled the police public relations to address marketing and other associated issues (Mawby 2001) because there are pieces of evidence that the social context of policing has changed, and the police accomplish public expectation which has become more assorted and fragmented (Mawby, 1999). Thus, the British police changed the name of their unit from the Metropolitan Force to the Metropolitan Service, the word "force" into "service" shows that they were trying to change the public's perception of the police, including also changing the self-image of each employee (Mawby and Worthington 2002).

The transformation from "force" to "service" occurred because of the impact of managerial reforms on the internal police force plus the public demands from the public sector for police officers to exhibit effective and efficient performance (Loader and Mulcahy 2003). Thus, finally, it changed how the police communicate with the community, and the interaction became more visible. Furthermore, communications become a crucial goal, so they feel the need to recruit professional communicators to improve images of police, formally and professionally (Mawby 2010).

In Indonesia, demands for disassociation between the Indonesian National Police and the Army began to emerge in the Reformation Era. These recommendations were made because of the different characteristics of the police and the armed forces (Muradi 
2007). The police are required to protect the community, while the armed forces implement security defenses and uphold the mantra of "all enemies must be destroyed." In 2002, according to Law Number 2 of 2002 on the Indonesian National Police, Law Number 3 of 2002 on National Defense, and Law Number 34 of 2004 on the Indonesian National Army by President Megawati Soekarno Putri, the duties and obligations of the National Police were separated from the Indonesian National Army. By being separated from the armed forces, it is assumed that the Indonesian National Police can complete their duties professionally, independently, and with accountability.

After being separated from the armed forces, the Indonesian National Police (INP) have made changes and innovations to improve their performance, involving the public perception about police being antagonistic to be a protagonist. The first change made by the Indonesian National Police (INP) was the restructuring of the organizational structure and provided extensive autonomy for the police to regulate their affairs (Yahya 1998). The Chief of the Indonesian National Police, who was under the President's command, finally made some strategic decisions to improve its reputation. In 2005, Indonesian National Police released Decree No.: SKEP / 360 / VI / 2005 about Grand Strategy for Indonesian National Police's performance improvement starting from 2005 - 2025 that consists of three stages. The first stage (2005 - 2010) is the Trust Building stage; the second stage (2010 - 2015) is called the Partnership stage, and the third stage (2015-2025) is the Strive for Excellence stage. These stages are priorities to be achieved to be professional, modern, and reliable Indonesian National Police. It is also essential for the police to cultivate good relationships among all stakeholders.

Three years later, the INP released Regulation of the Chief of the Indonesian National Police number 7 of 2008 about Basic Guidelines for Strategy and Implementation Community Policy in Managing INP's Duties. The changes in these rules are considered able to improve the police's reputation. Besides, the police also made a breakthrough in establishing communication with the community. For example, the INP tried to design television programs, produce commercial films, and set up official accounts on social media to maintain mutual understanding with the public. Even though these efforts have not been able to optimally improve the reputation of the Indonesian police during the reformation era (Arkam 2017; Baihaqi 2016; Farjina 2017; Tyas 1999) but signs of improving relations between the public and the INP are beginning to emerge.

According to Police Brigadier General Syahardiantono as the Head of Information and Documentation Management Bureau Police Public Relations of INP, since separating from the Indonesian National Army, the INP have become more flexible when dealing with the public. The INP started to coordinate with media partners regularly. The INP also schedules media visits to news agencies or inviting media partners to visit the Police Public Relations office at the Police Headquarters. Another informant, First Police Inspector Tyan Ludianan Prabowo, as the Administrative Officer of Service and Information Section Police Public Relations of INP, also emphasized that media partners can contact PR Police Headquarters any time. The INP even provides a particular group for media partners in the WhatsApp application so that coordination can be done 24 hours in 7 days. Even the Police Headquarters' Public Relations is preparing an integrated online information system that will make it easier for media partners to get information and data related to the INP. The ease, speed, and transparency of information performed by the police public relations finally made the news about the INP more positive and balanced compared to the previous period when 
they were still joining the Indonesian National Army.

\section{Police Image and Reputation to Enhance Mutual Understanding}

Historically, modern police began in 1829 in the United Kingdom. Robert Peel was the first Commissioner, while Rowan and Mayne engaged in developing positive images of police organization as one mechanism to encourage policing by consent and equal efforts to maintain legitimacy (Mawby and Worthington 2002). High-ranking police officers later made many changes to provide excellent service to the community by maintaining national security, improving the image of police institutions, and winning public trust.

In 2001, the new Home Secretary of the UK, David Blunkett, announced his decision to fundamentally reform the police service (Mawby and Worthington 2002). The minister's intention was subsequently set out in the white paper titled Policing a New Century published in December 2001. According to this report, in 1989, one of the British police forces, the Metropolitan Police Force has change edits name to Metropolitan Police Service. However, this is inadequate to show the spirit of the transformation in police organizations. They should be a complete reform on the structure with meticulous consideration given to "corporate identity" and "corporate image" (Mawby, 2002). According to Mawby (2002), again, this corporate identity refers to "what you want to tell the public," while the corporate image refers to "what the public says about you."

In the UK and central to any modern police forces, the police have passed four stages of creating positive image work of police, which falls under the umbrella of "image management" (Mawby, 2002): the First Period (1829 - 1919) - Informal Image Work, when the image work was uppermost in the elite mind but far removed from real police work; the Second Period (1919 - 1972) - Emergent Public Relations, when police institutions aware that news media play a significant contribution to the image work of police organizations; the Third Period (1972 - 1987) - Embedding Public Relations when Robert Mark as Metropolitan Police Commissioner facing crisis to rebuild the police image because of the corruption and crime, which had been done by senior officers; the Fourth Period (1987 - present) - Professionalization of Police Image Work, when Peter Imbert as Metropolitan Police Commissioner made policy for police language and communication techniques should be more often associated with the business and the commercial world rather than with policing. He changed the term "force" to "service" and pointed Wolff Olins as the corporate identity consultant for the Met who make British police more proactive than hitherto.

In fact, during the last two decades, police public relations have carried out the transformation. These transformations include transparency in the police and rules standardized, corporatized, professionalized, and more open to the public (Mcintee 2016). In the late 1980s, police units in the United Kingdom and the United States began to renew their internal managerial by replacing police officers assigned to the communications department. These officers were replaced by expert civilian practitioners (Wright 2002). The United States from 1994 - 1998 sent police aboard to 184 countries as in Haiti, Bosnia, and most recently, Timor Leste, to assist in the training, monitoring, and democratizing the police force to do a better job (Bayley 2001). It means that the modern police force understood that they have to improve the way to communicate with the community. Although control from the authority that has the power to regulate police policy still exists, as happened in Senegal.

In 1999, the Indonesian National Police made massive changes to the police 
institution. Since President Baharuddin Jusuf Habibie signed Presidential instruction No.2, which officially separated the police from military forces, the Indonesian National Police can independently make strategies and regulations according to police policies to protect the citizens. This role is different from the responsibilities of the armed forces, which tend to protect the country from any aggression. INP has made a strategy and regulations to improve the reputation of the police in the community. Nevertheless, the results in Table 1 showed that regardless of many internal regulations made, they still cannot positively improve the reputation of the police force because, in reality, they have never reached a 60 percent positive reputation (Siregar 2013).

Table 1. Percentage of INP Reputation From 2002 - 2012 (source: Siregar, 2013)

\begin{tabular}{|c|c|c|c|}
\hline Year & $\begin{array}{l}\text { The Chief of Indonesian National } \\
\text { Police }\end{array}$ & $\begin{array}{l}\text { The Number of } \\
\text { Regulations }\end{array}$ & $\begin{array}{c}\text { Positive } \\
\text { Reputation of INP } \\
\text { (in \%) }\end{array}$ \\
\hline 2002 & \multirow{4}{*}{$\begin{array}{c}\text { Da'i Bachtiar } \\
\text { (29 November } 2001-7 \text { July 2005) }\end{array}$} & & 26.6 \\
\hline 2003 & & & 41.8 \\
\hline 2004 & & & 32.4 \\
\hline 2005 & & 18 & 55.2 \\
\hline 2006 & \multirow{3}{*}{$\begin{array}{c}\text { Sutanto } \\
\text { (8 July 2005 - 30 September 2008) }\end{array}$} & 31 & 51.1 \\
\hline 2007 & & 26 & 46.9 \\
\hline 2008 & & 12 & 46.7 \\
\hline 2009 & \multirow{2}{*}{$\begin{array}{l}\text { Bambang Hendarso Danuri } \\
(1 \text { Oct } 2008-22 \text { Oct } 2010\end{array}$} & 18 & $\begin{array}{l}57.1 \\
\end{array}$ \\
\hline 2010 & & 27 & 49.1 \\
\hline 2011 & \multirow{2}{*}{$\begin{array}{c}\text { Timur Pradopo } \\
22 \text { Oct } 2010-25 \text { Oct 2013) }\end{array}$} & 26 & 53.0 \\
\hline 2012 & & 19 & 46.1 \\
\hline
\end{tabular}

From Table 1 above, in 2005 - September 2012, the National Police had at least 177 Regulations of Chief of Police, which mostly contained the substance of reform or internal governance of the police. The comparison between the positive reputations of the Indonesian National Police is fluctuating, and the number of Regulations has not contributed to the consistent positive reputation of the Indonesian National Police in public. In other words, Indonesian National Police reforms are still riddled with problems, one of which is easily detected, bottlenecks in implementing Chief of Police Regulations. For instance, the Chief of the Indonesian National Police ordered police officers to meet opinion leaders such as preachers, chaplains, and community leaders. There was also a suggestion for patrolling on foot to cultivate a close relationship with the community and establish excellent communication with reporters. However, in reality, police officers rarely meet opinion leaders, more often patrol using vehicles and sometimes intimidating journalists or media (Siregar, 2013).

Furthermore, since 2013, the Indonesian National Police has another directive: to conduct a Police Movie Festival annually. In 2017, the winner of this competition became a controversial issue because the short movie with the title "Kau adalah Aku yang Lain" (You are the Other Me) is considered a provocateur on the issue of racism. A 7-minute short film tells the story of a Catholic youngster who was in an emergency and must be taken to the hospital immediately. Unfortunately, the ambulance he was traveling in could not continue the trip because the road had been temporarily closed due to some Islamic activities. Then there was a dispute between three groups of people; the Muslims who refused to open the road, the moderate Muslims who favor opening the road, and the police who tried to open the way. This film is considered an attempt by 
the police to stigmatize Muslims as intolerant (Rizky 2017). The idea of conducting a film competition by the Indonesian National Police is appreciable because it could increase the intensity of communication with the community and improve the police's reputation via films that are pro INP produced by the public. Inappropriately, the implementation of its program became anticlimactic because the police were considered hostile to Islam with Islam's stigma as an intolerant religion.

The police institution can avoid the weaknesses and inaccuracies in making regulations to recover entente if only the police consider public relations' value and role because public relations have a strategic role in an organization (Dozier, Grunig, and Grunig 1995). Also, the police communication manager has to provide excellent service to the community on maintaining national security and improving the reputation of institutions in the community and winning public support (Mawby 2002).

In addition, there is a lack of knowledge in constructing a good reputation for the police institution. It is because many strategic managers in the INP do not fully understand the concept and function of public relations in the police institutions. Table 2 shows the ratio of managers in the police who have more background in police education than public relations.

Table 2 The Recapitulation of Personnel Composition (source: Documentation signed by the Chief of Indonesia National Police on 6 April 2017)

\begin{tabular}{|c|c|c|c|c|c|c|c|c|c|c|c|}
\hline Unit & & & POLRI & & & & & VIL & SERI & ANT & \\
\hline Bureau & $\begin{array}{l}\text { Insp. } \\
\text { General }\end{array}$ & $\begin{array}{c}\text { Brig. } \\
\text { General }\end{array}$ & $\begin{array}{l}\text { Grand } \\
\text { Com. }\end{array}$ & $\begin{array}{l}\text { Grand } \\
\text { Com } \\
\text { Adj. }\end{array}$ & Com & Total & IV & III & $\mathrm{II} / \mathrm{I}$ & Total & Total \\
\hline Head of PR & 1 & & & & & 1 & & & & $\mathbf{0}$ & 1 \\
\hline Administration & & & 1 & 3 & 3 & 7 & 4 & & 8 & 12 & 19 \\
\hline $\begin{array}{l}\text { Financial } \\
\text { affairs }\end{array}$ & & & & & & $\mathbf{0}$ & 1 & 4 & 4 & 9 & 9 \\
\hline $\begin{array}{l}\text { Public } \\
\text { information }\end{array}$ & & 1 & 3 & 6 & 1 & 11 & 3 & 6 & 8 & 17 & 28 \\
\hline $\begin{array}{l}\text { Information \& } \\
\text { Documentation }\end{array}$ & & 1 & 3 & 6 & 1 & 11 & 3 & 6 & 14 & 23 & 34 \\
\hline Multimedia & & 1 & 3 & 6 & 1 & 11 & 3 & 6 & 14 & 23 & 34 \\
\hline Total & 1 & 3 & 10 & 21 & 6 & 41 & 14 & 22 & 48 & 84 & 125 \\
\hline
\end{tabular}

Table 2 above shows that the number of civil servants is more than that of police officers. From the figures presented, the number of civil servants is two times the number of police. Nevertheless, the people in strategic positions are still high-ranking police officers who do not have formal education in communication science. Moreover, in most of Indonesia, public relations is not considered a strategic position. They are not allowed to become decision-makers; therefore, superiors make decisions, and public relations are only the implementers (Purbakusuma 2020). However, the leader who does not have public relations background are the ones who will make decisions about what public relations strategies will be implemented, and those civil servants who have public relations or communication background will carry out the orders. Whereas according to the excellence theory, public relations performance will be useful to improve the reputation but with the requirements of; 1) public relations is a strategic position that must be in managerial supported by dominant coalitions who know public relations functions, 2) as an independent bureau, and 3) has a symmetrical system of communication (Grunig and Grunig 2008). 
However, based on interviews with the informant, the Indonesian National Police has changed the recruitment system. In 2010, the police began recruiting scholars in various fields, including arts, sports, psychology, and communications (Muhammad Fajar, Recruitment, 14 September 2018). The staff in public relations who are not from a communication background must have training in photography, videography, news writing, media literacy, optimizing interactions in new media, and so forth (Muhammad Fajar, Training and Workshop, 17 March 2020). The police public relations also provide an opportunity for members to improve their abilities by continuing their education to the post-graduate level (First Police Inspector, Tyan Ludianan Prabowo, 19 February 2020). Based on the results of internal evaluations conducted by the police and the National Police Commission, staff with knowledge in communication can improve their ability to interact with the community effectively (Brigadier General Syahardiantono, 19 February 2020). As a cooling system, police public relations already know what kind of material can be delivered to the community to reduce the conflict's potential to become a bigger problem (Brigadier General Budi Setiawan, 3 March 2020).

Evidence that mutual understanding between the public and the police began to emerge was when a demonstration of the presidential election results in 2019. The INP gained public support because it was considered capable of reducing the conflict's intensity by displaying humanist police figures in the community.



Figure 1. The Viral Photo of Two Police Officer while Securing Demonstration (source: Instagram @masagungwilis)

Agung shares the photo (Picture 1) through his Instagram account @ masagungwilis on Wednesday morning (5/22/2019) with a caption "Election Supervisory Agency is busy. Meanwhile, feeling tired and homesick indeed true". The photo displayed two police officers leaning against each other. The eyes of one of the policemen were closed, while the other policeman was seen holding a cellphone. On the mobile screen, there was a picture of a small child. The police officer was in the middle of a video call with a child. The photo went viral; people began to support the police. Some of them shared stories that the officers are just like normal human beings, working to provide for their families. The photo boosted the police image and increased 
the understanding, support, and even defense of the police among the public.

There is another viral news that might improve the police image and increase mutual understanding between the police and the community. Such as the emergence of First Police Brigadier Norman Kamaru, whose video imitating Shahrukh Khan, is also positively accepted by the public. Thus, it is not surprising when Brigadier General Krishna Murti, who is considered a hero in handling the Sarinah Bombing terrorism case also emerged on YouTube. Another thing is the presence of Polisi Motret (translation: Police Captures Photos) YouTube channel, which belongs to a police officer, Chief Police Brigadier Herman Hadi Basuki. Polisi Motret has more than 600 thousand followers. That is a hundred times more than the followers of the official YouTube account of the police public relations of INP, which is no more than 6000 followers.

From the facts above, it proves that the Indonesian police have the potential to establish mutual understanding and good communication practices between the police and the community. However, the communication must be genuine and sincere. As Frist Police Brigadier Norman Kamaru and Chief Police Brigadier Herman Hadi Basuki did, they were present not because of a rigid and wordy strategy. As a matter of fact, it is very natural and close to the daily life of the community. If the police show rigid, formal, and high language videos, it will be difficult for the public to accept.

\section{Police on Media}

Press media have become police public relations partners for along time. Through news media, it would be easy for police public relations (PR) to construct a positive reputation among their public. In the mid-1970s, Chibnall argued that control agencies usually have three goals with the news media, namely: to protect the public reputation and the image of the control agency; to directly facilitate the work of the control agency in controlling and apprehending deviants; and to promote the particular aims, ideologies, and interests of members of the control agency (Chibnall 1977).

The police public relations must maintain good relations and be open to the mass media by developing media management expertise, avoiding saying "no comment", improving openness, transparency, and aligning communication and activities with a system of accountability (Mawby, 1999). Subsequently, it is almost demanding for a public relations practitioner to do those tasks if they do not have excellent communication knowledge. According to Chibnall, police PR have to know that to attract mass media, crime news provides certain values such as immediacy, dramatization, and novelty (McGovern and Lee 2010) instead of dichotomies story which leads to being boring news.

The next step is to realize that to build a positive image depends not just on how much the police public relations power to regulate public relations strategies and tactics, but also on their creativity in designing it. Moreover, the image of the police is also influenced by their routine activities and not only what is reported in the media (Mawby, 2002). Consequently, being a police public relations officer must continuously evaluate the strategies with internal and external challenges in order to be able to do their job well.

As one of the duties of the Indonesian police to establish a mutual understanding with all stakeholders, they have also prepared various communication tools to reach all communities. Besides having continuous communication with the press and media partners, they also have several programs to improve their image, such as a TV program. On 2 August 2014, NET TV, one of the Indonesian private television stations 
in collaboration with the Indonesian National Police, produced an 86 (Delapan Enam in Bahasa) program. The program's name comes from the INP code, which means 'it is understood' or 'copy that'. The 86 program is a reality show that demonstrates the daily police life in carrying out their duties ranging from curbing traffic violators to uncovering drug syndicates. The " 86 " production team will follow and record several police officers who have been determined earlier to provide an overview to the audience of what and how the police do their work process and what happens if someone breaks the law. Studies reports that 86 programs succeeded in increasing the police reputation because it provides a holistic picture of the nitty-gritty of police work and the hardship of police officers while performing their duties (Baihaqi 2016; Farjina 2017; Sas 2015). Besides, the Indonesian National Police is also the primary source for journalists when they need sources from the government because the information from police officers is considered an accurate source of information and allows cyber media to report immediately (Loisa et al., 2019).

After disassociation with the Army, the Indonesian National Police started to collaborate to produce a movie about the INP. Until 2019, at least there were 5 Indonesian national movies, which depicted the story of the Indonesian National Police. Firstly, Jakarta Hati in 2012 that consists of 6 stories; one of the stories tells about an INP officer who experienced the dilemma of serving justice because the culprit was his father. The second film, produced in 2018 entitled 22 Menit, tells about a policeman who is also a member of the anti-terrorism unit trying to hunt down the perpetrators of the Sarinah bombing on MH Tamrin Jakarta. Lastly, in 2019 the public relations department of the Indonesian National Police officially released three commercial films consecutively. Pohon Terkenal (the Famous Tree) is a romantic comedy that portrays a romantic relationship between the students in the Indonesian Police Academy. This film was released in March 2019 while another film, Hanya Manusia (Only a Human) which was a drama about the inner conflict of a female police officer who faces a dilemma between her family and work and Sang Prawira (the Officer) tells the story of the struggle of a young man undergoing police training.

According to an interview with the informant, Muhammad Fajar, after screening the Pohon Terkenal film in March 2019, which is exactly a month before registration to the police academy, the number of registrants in that period is more than the previous period (Muhammad Fajar, Police on Media, 20 July 2020). Although there is no internal research or evaluation related to the cause-and-effect relationship between the film and the increasing number of applicants, it could indicate that establishing a mutual understanding relationship with the public and the INP can also use film.

Thus, the Indonesian National Police also do the image work for their institution by using new media. By using this new technology, the INP can provide two-way communication and construct mutual understanding with the community. New media is the right tool to communicate with the Indonesian citizen since CNN reporter Sara Sidner (2010) pointed out: "Indonesia is crazy about online social networking ... but all the Tweeting, texting, and typing is not just for fun. It is also being used as a tool for change." Characterized by convergence, low cost, broad availability, and good resistance to and censorship, the Internet is a "convivial medium." The nation's net population reached 83.7 million people in 2014 and ranked Indonesia as the 6th largest Internet user in the world (Wicak 2014). This makes social media a useful tool to maintain mutual understanding and equal communication to create a good image of the Indonesian National Police. 
Unfortunately, the efforts they make on social media do not directly have a good impact on the image of the police. Their official accounts often get nasty comments, scorn, cynicism, innuendo, and bullying (Kartika 2009; Masya et al. 2012; Nasrullah 2015). Some offline phenomena such as snuggery, nepotism, and corruption by the police officers were recorded and captured by citizens, making a mutual understanding between the two sides more difficult.

\section{Conclusion}

The police need the support of the community. The most effective way to get that support is by starting to build mutual understanding with the public. Consequently, the Indonesian National Police must keep trying to establish effective communication with the community either by patrolling, giving lectures, engaging in community activities including using communication media to establish communication with the public. Nevertheless, building relationships with the community is not easy for police institutions, including for the Indonesian National Police. It is because the community has high expectations for the performance of the police.

However, this resarech should be continued with further research in more detail with the police in other countries with different characteristics from Indonesia. The more references regarding public relations in the police, the more instructions can be done by police's public relations to work. With these ideals, the police performance to gain mutual understanding, trust, and public support are more effective.

\section{References}

Arkam, Amalia Megawati. 2017. "Strategi Komunikasi Bidang Humas Kepolisian Daerah Sulawesi Selatan Dalam Mengelola Citra Positif Polisi Di Masyarakat.” Universitas Hasanuddin.

Baihaqi, Muhammad Imam. 2016. "Konstruksi Realitas Sosial Citra Polisi Pada Reality Show Net '86' Di Net TV.” Universitas Islam Negeri Syarif Hidayatullah.

Bayley, David H. 2001. "Democratizing the Police Abroad: What to Do and How to Do It.” Issues in International Crime, US Department of Justice 126.

Bhattacherjee, Anol. 2012. Social Science Research: Principles, Methods, and Practices. Vol. 61. Florida: Anol Bhattacherjee Published.

Board, The Editorial. 2020. "How the Supreme Court Lets Cops Get Away with Murder." The New York Times.

Broom, Glen M., and Bey-Ling Sha. 2013. Cutlip and Center's: Effective Public Relations. eleventh e. England: Pearson Education Limited.

Brown, M. Craig, and Barbara D. Warner. 1992. "Immigrants, Urban Politics, and Policing in 1900." American Sociological Review 57(3):293-305.

Chibnall, Steve. 1977. Law and Order News: An Analysis of Crime Reporting in the British Press. London and New York: Routledge.

Cooke, Louise, and Paul Sturges. 2009. "Police and Media Relations in an Era of Freedom of Information." Policing and Society 19(4):406-24.

Dozier, David M., Larissa A. Grunig, and James E. Grunig. 1995. Manager's Guide to Excellence in Public Relations and Communication Management. ebook. New York: Routledge.

Farjina, Nofitri Nur. 2017. "Pencitraan Positif POLRI Dalam Acara '86' Di Net TV Di Masyarakat Kota Salatiga." Universitas Kristen Satya Wacana.

Grunig, James E., and Larissa A. Grunig. 2008. "Excellence Theory in Public Relations: 
Past, Present, and Future." Pp. 327-48 in Public Relations Research European and International Perspectives and Innovations, edited by A. Zerfass, B. Van Ruler, and K. Sriramesh. Netherlands: VS Verlag für Sozialwissenschaften.

Kadar, Andras, ed. 2001. Police in Transition Essay on the Police Forces in Transition Countries. New York: Central European University Press.

Kartika, Dea. 2009. "REPRESENTASI CITRA POLRI DALAM FOTO SATIRE DI SITUS 9GAG." (071015052).

Kocon, Pawel, and Dariusz Kryszk. 2015. "The Role of Public Relations in Public Social Partnership of Polish Armed." 4(32):325-32.

Loader, Ian, and Aogan Mulcahy. 2003. Policing and the Condition of England. New York: Oxford University Press.

Loisa, Riris, Eko Harry Susanto, Ahmad Junaidi, and Felicia Loekman. 2019. "Media Siber, Aparat Dan Pemberitaan Keberagaman.” Jurnal ASPIKOM 3(6):1243-53.

Marenin, Otwin, and M. Caparini. 2004. "Transforming the Police in Central and Eastern Europe.” Dcaf 2003(2002).

Masya, Fajar, Elvina, and Fitri Maria Simanjuntak. 2012. "Sistem Pelayanan Pengaduan Masyarakat Pada Divisi Humas Polri Berbasis Web." Seminar Nasional Aplikasi Teknologi Informasi 2012 (SNATI 2012) 2012(Snati):1-6.

Mawby, Rob C. 2001. "Promoting the Police? The Rise of Police Image Work." Criminal Justice Matters 43(1):44-45.

Mawby, Rob C. 2002. Policing Images: Policing, Communication and Legitimacy. Willan Publishing.

Mawby, Rob C. 2009. "Understanding Criminal Justice through Analysing Its Communication." Criminal Justice Matters 78(1):15-17.

Mawby, Rob C. 2010. "Police Corporate Communications, Crime Reporting and the Shaping of Policing News." Policing and Society 20(1):124-39.

Mawby, Rob C. 2014. "The Presentation of Police in Everyday Life: Police-Press Relations, Impression Management and the Leveson Inquiry." Crime, Media, Culture 10(3):239-57.

Mawby, Rob C., and Steve Worthington. 2002. "Marketing the Police - from a Force to a Service." Journal of Marketing Management 18:857-76.

McGovern, Alyce, and Murray Lee. 2010. “Cop [Ying] It Sweet': Police Media Units and the Making of News." Australian and New Zealand Journal of Criminology 43(3):444-64.

Mcintee, Victoria. 2016. "Police Public Relations in the Age of Social Media." Canterbury Christ Church University.

Muradi. 2007. "Penantian Yang Panjang: Reformasi Polri Menuju Democratic Policing." (September).

Muradi. 2014. Politics and Governance in Indonesia: The Police in the Era of Reformasi. New York: Routledge.

Muradi. 2016. "Polri Dalam Pusaran Penilaian Publik." Jurnal Ilmu Pemerintahan 1(2):240-48.

Nasrullah, Rulli. 2015. "Perundungan Siber (Cyber-Bullying) Di Status Facebook Divisi Humas Mabes Polri." Jurnal Sosioteknologi 14(1):1-11.

Nielsen, Suzanne C. 2005. "Civil-Military Relations Theory and Military Effectiveness." Public Administration and Management 10(2):61-84.

Nielson-Green, Lieutenant Colonel Rumi. 2011. "What Can We Do?" (August).

Nielson-green, Lieutenant Colonel Rumi, and U. S. Army. 2011. "Fighting the 
Information War but Losing Credibility. What Can We Do?" (August).

Offerdahl, Thomas G. 2016. "A Systemic Analysis of the Challanges of Policing Senegal: The Role of The Police in Democracy." University of Scranton.

Purbakusuma, Angga Intueri Mahendra. 2020. "Simplification of the Role of Public Relations." Jurnal ASPIKOM 5(1):102-14.

Reeves, Nicholas. 1999. The Power of Film Propaganda: Myth or Reality? 2nd ed. New York: Continuum.

Rizky, Fahreza. 2017. "Film 'Kau Adalah Aku Yang Lain' Berpotensi Memukul Toleransi Yang Sudah Terbangun."

Sas, Bramanthy Cecariya. 2015. Pengaruh Program "86" Di Net TV Terhadap Persepsi Citra Polisi Wanita (Studi Pada Followers Twitter @ 86Netmedia). Jakarta.

Siregar, Sarah Nuraini. 2013. PENCAPAIAN REFORMASI INSTRUMENTAL POLRI 1999-2011 ACHIEVEMENT OF THE INSTRUMENTAL INDONESIAN NATIONAL POLICE REFORM.

Tellis, Winston. 2014. "Application of a Case Study Methodology." The Qualitative Report 3(1988):1-17.

Tyas, B. Hari Saptaning. 1999. "Persepsi Masyarakat Dan Polisi Terhadap Kinerja Kepolisian (Studi Di Provinsi Daerah Istimewa Yogyakarta).” Universitas Gajah Mada.

Wicak, Hidayat. 2014. "Pengguna Internet Indonesia Nomor Enam Dunia." Kominfo. Retrieved (https://kominfo.go.id/index.php/content/detail/4286/Pengguna+Internet+Indonesi a+Nomor+Enam+Dunia/0/sorotan_media).

Wright, Alan. 2002. Policing: An Introduction to Concepts and Practice. 1st ed. London: Routledge.

Yahya, Nur. 1998. "Penataan Kembali Organisasi Kepolisian Republik Indonesia Untuk Mewujudkan Kemandirian Dan Profesionalisme." Universitas Diponegoro.

Yanow, D., Schwartz-Shea P., and M. J. Freitas. 2008. "Case Study Research in Political Science." Encyclopedia of Case Study Research 109-14. 